\title{
Association of Nutritional Status and Physical Activity Level with Pneumonia in Indonesian Urban Area
}

\author{
Yuli Dwi Setyowati ${ }^{*}$, Anton Suryatma ${ }^{2}$, Tities Puspita ${ }^{2}$ \\ ${ }^{1}$ Department of Nutrition, University of Muhammadiyah Prof. Dr. Hamka, \\ South Jakarta 12130, Indonesia \\ ${ }^{2}$ National Institute of Health Research and Development, Indonesian Ministry of Health, \\ Jakarta 10560, Indonesia
}

\begin{abstract}
The study aimed to overview and analyze the relationship between nutritional status, physical activity and pneumonia in a community in South Jakarta. We analyzed the secondary data from the 2016-2018 The Programme of Knock on Doors and Serve with Heart (Ketuk Pintu Layani Dengan Hati) (KPLDH) census for the Tebet District in South Jakarta. The census involved 58,627 samples, which were divided into three age groups: children $<5$ years old, adolescents, and adults. We measured the nutritional status of children $<5$ years old using the Weight/Height Ratio (WHR) category (z-score), adolescents with Body Mass Index (BMI)/age (z-score) and adults with BMI $\left(\mathrm{kg} / \mathrm{m}^{2}\right)$. Physical activity was measured for adults and adolescent only and categorized as "routine" and "non-routine". The highest prevalence of pneumonia was found in samples with non-routine physical activity and in adults. Most of the adults who had pneumonia were also had normal nutritional status. Adults with Chronic Energy Deficiency (CED) and Severe CED (S-CED) had a higher risk of having pneumonia OR=8.465; 95\% CI:5.478-13.081 for S-CED and OR=3.210; $<<0.05 ; 95 \%$ CI:1.895-5.438 for CED respectively compared to those with normal weight. Adults and adolescents with routine physical activity had a lower risk of having pneumonia (OR=0.496; 95\% CI:0.320-0.767). Further studies are also needed concerning the relationship of pneumonia with other determinants such as socio-economic status, environmental issues, and nutritent intake.
\end{abstract}

Keywords: nutritional status, physical activity, pneumonia

\section{INTRODUCTION}

Pneumonia is a dangerous inflammatory condition of the lungs that can cause death. The prevalence of pneumonia increases along with age, however an annual of 920 thousand child deaths can be attributed to pneumonia (UNICEF 2016; McAllister 2019). In Indonesia, the 2018 estimated number of pneumonia-related deaths in children under the age of five was 19 thousand cases (UNICEF 2018). The national capital, DKI Jakarta was one of the seven provinces with the highest number of pneumonia cases (Kemenkes 2013). The prevalence of people with pneumonia in DKI Jakarta is around 2.3\% which is higher than the national prevalence $(2 \%)$.

The emergence of pneumonia can be caused by poor nutritional status and low physical activity (Nurnajiah 2016; Pape 2016). Children and adults suffering from malnutrition are more susceptible to infection than those with good nutritional status (Nurnajiah 2016; Tongo 2017). Lack of protein in people with malnutrition can cause thymus atrophy, which disrupts the $\mathrm{T}$ cell production. This in turn also disrupts the antibodies as humoral immunity. Lack of protein can also lead to the lack of certain kinds of micronutrients (Darwin 2006; Cripps 2008; Nurnajiah 2016).

On the other hand, low physical activity is associated with an increased risk of developing respiratory infections and acute pneumonia (Pape 2016; Sato 2016). Almost half (47.8\%) of the DKI Jakarta population had low physical activity level (Kemenkes 2018). This has increased from $44.2 \%$ in the previous national survey (Kemenkes 2013).

The DKI Jakarta Provincial Health Office has taken a family approach in developing a program called The Programme of Knock on Doors and Serve with Heart (Ketuk Pintu Layani Dengan Hati) (KPLDH). This health

"Corresponding Author: tel: +6285773417877, email: yulisetyowati@uhamka.ac.id 
service program aims to restore the concept of community support for health promotion and prevention activities. The KPLDH started with household level data collection on 12 indicators of a healthy family, family planning data and Riskesdas data (PERGUB 2016). The KLPLDH analysis showed high prevalence of pneumonia in Tebet community in South Jakarta. Thus, based on the above-mentioned associations between nutritional status, physical activity level with pneumonia the researchers were interested in exploring these associations in the community of Tebet, in South Jakarta.

\section{METHODS}

\section{Design, location, and time}

This study was a secondary data analysis of the KPLDH family data survey conducted in Tebet District, South Jakarta from January 2016December 2018.

\section{Sampling}

The survey population were 233,237 people who resided in Tebet sub district for more than 5 years in 2016-2018 (BPS Jaksel 2018). A total of 82 thousand $(35.16 \%)$ of the population were surveyed, however 23,373 of the respondents dropped out from the study. Subsequently, we analyzed the remaining data from 58,627 subjects.

\section{Data collection}

The KPLDH survey was done door to door where the enumerators brought weight and height/length scales of the same brand for each team. They came to eight villages, where one team collected data from up to ten thousand subjects from each village. Data obtained for this study included the characteristics of the respondents, their physical activity, and the nutritional status of the children, adolescents and adults in the households.

\section{Data analysis}

The subjects were grouped based on sex and age. The age groups were: children $<5$ years old, adolescents (9-18 years old) and adults (19-66 years old). Physical activity data was taken only for adolescent and adult respondents and categorized into routine and non-routine. Routine physical activity was defined as conducting physical activity more than five days a week.
The nutritional status of children $<5$ years old was measured based on Weight/Height Ratio (WHR) category (z-score). Whereas the nutritional status of adolescents was measured using BMI/age (z-score) and BMI $\left(\mathrm{kg} / \mathrm{m}^{2}\right)$ for adults aged 19-66 years. These are the standard categories of nutritional status according to the Decree of the Ministry of Health Indonesia Anthropometry 2010 (Kemenkes 2010).

The statistical analysis was performed using the SAS software. The Univariate analysis was used to describe the distribution of age, gender, nutritional status, physical activity and pneumonia. Chi-square test was conducted to identify the relationship between physical activity and pneumonia, and nutritional status (children $<5$ years old, adolescents and adults) and pneumonia. A significance was set at $p$-value of 0.05$)$.

\section{RESULTS AND DISCUSSION}

\section{Subject characteristics, nutritional status, physical activity}

The study subjects were mostly adult (73.60\%), followed by adolescents (21.01\%) and under-fives $(5.39 \%)$. The male and female subjects was of equal number (Table 1). The nutritional statuses for the children $<5$ years old and adolescents were categorized as normal $(55.34 \%$ and $66.10 \%)$ respectively. While for adults almost half $(48.32 \%)$ were in the normal category (Table 2 ).

Despite the fact that most of the subjects aged $<5$ years old had normal body weight, we found that almost a quarter $(24.03 \%)$ of all subjects were underweight or severely-underweight. The prevalence of severe underweight was $12.95 \%$, while the national prevalence was $10.2 \%$ in 2018 and $12.1 \%$ in 2013 report (Kemenkes 2018; Kemenkes 2013). On the other hand, the prevalence of overweight in this age group was $20.64 \%$ and this is above the national prevalence (11.8\% in 2013 and 8\% in 2018). This indicates that Tebet had a higher prevalence of under-fives who were severely-underweight and overweight compared to the national prevalence both based on the 2018 and 2013 national prevalence in the same age group.

For the adolescents and adults, overweight and obesity were a more common nutrition issue. The prevalence of obesity and overweight in 
Table 1. Subject distribution based on age and sex

\begin{tabular}{llcc}
\hline \multirow{2}{*}{ Characteristics } & \multicolumn{2}{c}{ Total } \\
\cline { 3 - 4 } Age & & $\mathrm{n}$ & $\%$ \\
\cline { 2 - 3 } & Under five years & 2,951 & 5.39 \\
& Adolescents & 11,490 & 21.01 \\
& Adults & 40,242 & 73.59 \\
Sex & & & \\
& Female & 27,620 & 50.51 \\
& Man & 27,063 & 49.49 \\
\hline
\end{tabular}

adolescent was $30.32 \%$ and it was $42.19 \%$ in adult. While the prevalence of Chronic Energy Deficiency (CED) and severe CED in adolescent was $3.58 \%$ and $9.5 \%$ in adult. In addition to the overweight and obesity prevalence, the majority of subjects $(78.28 \%)$ had non-routine physical activity (Table 2). This finding is in line with the Kemenkes (2018) research results, indicating a high number of low physical activity $(44.70 \%)$ in the DKI Jakarta.

\section{Pneumonia}

There were 408 subjects with pneumonia in the study; 13 children $(0.44 \%)$; 34 adolescents $(0.30 \%)$ and 157 adults $(0.39 \%)$. The nutritional status of the adolescents and adults who had pneumonia was mostly in the normal weight category. The prevalence of pneumonia in adolescent and adult with normal nutrition status were $0.19 \%$ and $12.9 \%$ respectively. However, in adult we found 54 subjects with pneumonia who had severe and Chronic Energy Deficiency (CED). This is in line with Dobner and Kaser's research (2018), which states that adolescents and adults living in developing countries tend to be at risk of developing infectious diseases, especially pneumonia, if they are severely underweight.

\section{The relationship between nutritional status, physical activity and pneumonia}

Adult with Severe Chronic Energy

Eeficiency (S-CED) had a statistically significant risk of having pneumonia $(\mathrm{OR}=8.465 ; \mathrm{p}<0.05$; 95\% CI:5.478-13.081) compared to those with normal weight. We also found that underweight adults (CED) also had a higher risk of suffering from pneumonia $(\mathrm{OR}=3.210 ; \mathrm{p}<0.05 ; 95 \%$ CI:1.895-5.438) compared to adults with normal weight, although the risk was lower than the S-CED (Table 2). Thus, adult with low nutritional status, indicated by S-CED and CED had an increased risk of having pneumonia compared to adults with normal nutritional status. These results are consistent with previous studies showing that pneumonia was more commonly found in adults with malnutrition (Dobner \& Kaser 2018; Tongo 2017).

Malnutrition can reduce the strength of the abdominal muscles and diaphragm during the process of respiration, resulting in the impaired ventilation function in the respiratory tract, so that the ability to expel phlegm is disrupted and exudates accumulate in the bronchi. Disruption of this expectoration process will aggravate the condition and can cause bronchopneumonia (Arisman 2010; Adriani 2012).

Patients with malnutrition also showed a decrease in IgA levels, where IgA serves to protect the upper respiratory tract from infection by pathogenic organisms. Therefore, a decrease in IgA levels results in a decrease in the immune system of the airways, exacerbating the degree of respiratory tract infection (Rodriguez 2011).

In addition, lack of protein in malnutrition can lead to thymus atrophy, disrupting the $\mathrm{T}$ cell production as well as the antibody production as humoral immunity. Furthermore, lack of protein can also leads to micronutrients deficiency including vitamin A, vitamin E, vitamin B6, vitamin $C$, folate, zinc, iron, copper and selenium. The deficiency of these micronutrients results in decreasing antibody formation (Darwin 2006; Cripps 2008; Nurnajiah 2016).

When comparing between non-routine physical activity and routine physical activity amongst adult and adolescent, we found that physical activity lowers the odd of having pneumonia $(\mathrm{OR}=0.496 ; \mathrm{p}<0.05 ; 95 \% \mathrm{CI}: 0.320$ $0.767)$. This shows that people who routinely performed physical activities will be 50\% less likely to develop pneumonia compared to people who do not routinely engage in physical activity. This finding is in accordance to Katzmarzyk 's research (2015), which shows that people who had low physical activity are at risk of developing respiratory infections compared to those who often exercise. In addition, low physical activity is associated with an increased risk of the recurrence of contracting respiratory tract infections (Tomatala 2019). Doing exercise is 
Table 2. Subject distribution based on physical activity, nutritional status and pneumonia

\begin{tabular}{|c|c|c|c|c|c|c|c|c|}
\hline \multirow{2}{*}{ Variables } & \multicolumn{2}{|c|}{ Total } & \multicolumn{2}{|c|}{ Pneumonia } & \multirow{2}{*}{ OR } & \multirow{2}{*}{$\mathrm{p}$} & \multirow{2}{*}{\multicolumn{2}{|c|}{$95 \% \mathrm{CI}$}} \\
\hline & $\mathrm{n}$ & $\%$ & $\mathrm{n}$ & $\%$ & & & & \\
\hline \multicolumn{9}{|l|}{ Physical activity } \\
\hline Non-routine & 42,806 & 78.28 & 174 & 0.318 & - & - & - & - \\
\hline Routine & 11,877 & 21.72 & 30 & 0.101 & 0.496 & 0.002 & 0.320 & 0.767 \\
\hline \multicolumn{9}{|l|}{ Children body mass index } \\
\hline Severe-underweight & 382 & 12.95 & 4 & 0.136 & 0.553 & 0.577 & 0.069 & 4.436 \\
\hline Underweight & 327 & 11.08 & 7 & 0.237 & 0.643 & 0.677 & 0.080 & 5.155 \\
\hline Normal $^{* *}$ & 1,633 & 55.34 & 2 & 0.068 & - & - & - & - \\
\hline Overweight & 609 & 20.64 & 0 & 0.000 & 1.011 & 0.987 & 0.268 & 3.823 \\
\hline \multicolumn{9}{|l|}{ Adolescents body mass index } \\
\hline Severe-underweight & 275 & 2.39 & 0 & 0.000 & - & - & - & - \\
\hline Underweight & 137 & 1.19 & 2 & 0.017 & 2.567 & 0.358 & 0.344 & 19.171 \\
\hline Normal $^{* *}$ & 7,595 & 66.10 & 22 & 0.191 & - & - & - & - \\
\hline Overweight & 1,776 & 15.46 & 2 & 0.017 & 0.411 & 0.228 & 0.096 & 1.748 \\
\hline Obese & 1,707 & 14.86 & 8 & 0.070 & 1.718 & 0.191 & 0.764 & 3.865 \\
\hline \multicolumn{9}{|l|}{ Adults body mass index } \\
\hline Severe - underweight (S-CED) & 1,621 & 4.03 & 35 & 0.087 & 8.465 & 0.000 & 5.478 & 13.081 \\
\hline Underweight (CED) ${ }^{*}$ & 2,202 & 5.47 & 19 & 0.047 & 3.210 & 0.000 & 1.895 & 5.438 \\
\hline Normal $^{* *}$ & 19,444 & 48.32 & 52 & 0.129 & - & - & - & - \\
\hline Overweight & 7,612 & 18.92 & 25 & 0.062 & 1.215 & 0.425 & 0.753 & 1.959 \\
\hline Obese & 9,363 & 23.27 & 26 & 0.065 & 1.016 & 0.944 & 0.635 & 1.629 \\
\hline
\end{tabular}

${ }^{*}$ Underweight or Chronic Energy Deficiency (CED); ${ }^{*}$ Normal as standard on measurement

one way to maintain the immune system, optimal physical activity will help boost the immune by increasing the blood flow to the brain during activities (James et al. 2008).

However, we found conflicting evidence regarding the associations between nutritional status and pneumonia in children under the age of five $(\mathrm{p}>0.05 ; \mathrm{OR}=0.553 ; 95 \%$ CI:0.0694.436) and adolescents ( $\mathrm{p}>0.05 ; \mathrm{OR}=2.567 ; 95 \%$ CI:0.344-19.171). Several studies also found no significant correlation between nutritional status and pneumonia in children (Rachmawati 2013; Widayat 2014; Pramono \& Purwati 2018). However, Rohimah et.al (2015) and Saha et.al (2016) showed that infectious diseases in children were related to the low weight for age and nutritional status (weight/age). This evidence however, does not indicate that malnutrition is not an important factor for developing pneumonia in children and adolescent. Hence, this evidence suggests that there are many other factors that more strongly associated to pneumonia in children and adolescent in our study area thus in need of further study.

The strength of this study was the use of big data from the KPLDH family data survey. Meanwhile, its limitations were that the data was only for limited variables such as the nutritional statuses of children 0-5 years old, adolescents aged 9-18 years old, and adults aged $19-66$ years 
Nutritional status, physical activity and pneumonia

old, as well as physical activity data for only adolescences and adults.

\section{CONCLUSION}

This study revealed that in Indonesian urban area, there was a high prevalence of pneumonia found in adults and underweight was significantly associated with higher risk of pneumonia. In addition, routine physical activity was associated with lower risk of pneumonia in adults and adolescents. This study suggests the need to encourage people to attain normal nutritional status and increase their physical activity to curb the rise pneumonia in urban communities. This can be achieved by conducting massive health promotion program. Further studies are also needed concerning the relationship of pneumonia with other determinants such as socio-economic status, environmental issues, and nutritional intake.

\section{ACKNOWLEDGEMENT}

The researcher would like to thank the Ministry of Health Indonesia and Public Health Service of South Jakarta, who granted the permission to use The programme of Knock on Doors and Serve with Heart (Ketuk Pintu Layani Dengan Hati) (KPLDH) survey data.

\section{AUTHOR DISCLOSURES}

The authors have no conflict of interest.

\section{REFERENCES}

Adriani M. 2012. Peranan Gizi dalam Siklus Kehidupan. Jakarta (ID): Kencana Pranadamedia Group.

Arisman. 2010. Gizi dalam Daur Kehidupan. Edisi 2. Jakarta (ID): EGC

[BPS Jaksel] Badan Pusat Statistik. 2018. Kecamatan Tebet dalam Angka 2018. https://jakselkota. bps.go.id/publication/2018/09/26/ bd501fe9f4042142124fe11f/kecamatantebet-dalam-angka-2018.html. [Accessed 28th August 2019].

Cripps A, Diana CO, Jane P, Deborah L, Michael PA. 2008. The relationship between undernutrition and humoral immune status in children with pneumonia in Papua New Guinea. PNG Med J. Vol 51(3/4):120-130.

Darwin E. 2006. Imunologi dan Infeksi. Padang (ID): Andalas University Press.

Dobner J, Kaser S. 2018. Body mass index and the risk of infection-from underweight to obesity. Clinical Microbiology and Infection 24(1):24-28. https://doi. org/10.1016/j.cmi.2017.02.013.

James J, Baker C, Swain H. 2008. Prinsip-Prinsip Sains untuk Keperawatan. Jakarta (ID): Erlangga.

[Kemenkes RI] Kementerian Kesehatan RI. 2010. Keputusan Menteri Kesehatan Republik Indonesia Nomor: 1995/Menkes/SK/ XII/2010 Tentang Standar Antropometri Penilaian Status Gizi Anak. Jakarta (ID): Kemenkes RI.

[Kemenkes RI] Kementerian Kesehatan RI. 2013. Riset Kesehatan Dasar. Jakarta (ID): Badan Penelitian dan Pengembangan Kesehatan Kemenkes RI.

[Kemenkes RI] Kementerian Kesehatan RI. 2018. Riset Kesehatan Dasar. Jakarta (ID): Badan Penelitian dan Pengembangan Kesehatan Kemenkes RI.

Katzmarzyk PT, Barreira TV, Broyles ST, Champagne CM, Chaput JP, Fogelholm M, Hu G, Johnson WD, Kuriyan R,Kurpad A et al. 2015. Relationship between lifestyle behaviors and obesity in children ages 9-11: Results from a 12-country study. Obesity 23(8):1696-1702. https:// doi.org/10.1002/oby.21152.

McAllister DA, Liu L, Shi T, Chu Y, Reed C, Burrows J, Adeloye D, Rudan I, Black RE, Campbell $\mathrm{H}$ et al. 2019. Global, regional, and national estimates of pneumonia morbidity and mortality in children younger than 5 years between 2000 and 2015: A systematic analysis. Lancet Glob Health 7(1):e47-e57. https://doi. org/10.1016/S2214-109X(18)30408-X.

Nurnajiah M, Rusdi R, Desmawati D. 2016. Hubungan status gizi dengan derajat pneumonia pada balita di rs. dr. m. djamil Padang. Jurnal Kesehatan Andalas 15(1): 250-255. https://doi.org/10.25077/jka. v5i1.478.

[PERGUB DKI]. Peraturan Gubernur Provinsi Daerah Khusus Ibu Kota Jakarta. 2016. Nomor 115 tahun 2016 tentang Program 
Ketuk Pintu Layani Dengan Hati. Jakarta: Berita Daerah Provinsi Khusus Ibu Kota Jakarta. https://www.google.com/url?sa=t $\& \mathrm{rct}=\mathrm{j} \& \mathrm{q}=\&$ esrc $=\mathrm{s} \&$ sourceweb \& $\mathrm{cd}=\& \mathrm{v}$ ed=2ahUKEwitxPO2nJbsAhVNOisKHdl fBikQFjACegQIARAC\&url=https $\% 3 \mathrm{~A} \%$ $2 \mathrm{~F} \% 2 \mathrm{Fwww}$.regulasip.id\%2Felectronicb o o k \% 2 F $14500 \&$ u g $=\mathrm{A} \mathrm{O} \mathrm{v}$ Vaw 1 jhrGw 8 N4S VBRuu0R7yFjq. [Accessed 23rd August 2019].

Pape K, Ryttergaard L, Rotevatn TA, Nielse BJ, Torp-Pedersen C, Overgaard C, Bøggild H. 2016. Leisure-time physical activity and the risk of suspected bacterial infections. Med Sci Sports Exerc 48(9):1737-1744. https://doi.org/10.1249/ MSS.0000000000000953.

Pramono PS, Purwati NH. 2018. Faktor-faktor yang berhubungan dengan kekambuhan pada anak balita dengan pneumonia di rsab harapan kita. Indonesian Journal of Nursing Sciences and Practice 1(1):1-7. https://doi.org/10.24853/ijnsp.v1i1.1-7.

Rachmawati DA. 2013. Faktor risiko yang berhubungan dengan kejadian pneumonia pada balita umur 12-48 bulan di wilayah kerja puskesmas mijen kota Semarang. Jurnal Kesehatan Masyarakat Dipenogor 2(1):18842. http://ejournals1.undip.ac.id/ index.php/jkm

Rodriguez L, Cervantes E, Ortiz R. 2011. Malnutrition and gastrointestinal and respiratory infections in children: A public health problem. Int $\mathrm{J}$ Environ Res Public Health 8(4):1174-1205. https://doi. org/10.3390/ijerph8041174.

Rohimah E, Kustiyah L, Hernawati N. 2015. Pola konsumsi, status Kesehatan dan hubungannya dengan status gizi dan perkembangan balita. Jurnal Gizi dan Pangan 10(2):93-100. https://doi. org/10.25182/jgp.2015.10.2.\%25p .

Saha S, Hasan M, Kim L, Farrar JL, Hossain B, Islam M, Ahmed ANU, Amin MR, Hanif M, Hussain M et al. 2016. Epidemiology and risk factors for pneumonia severity and mortality in Bangladeshi children $<5$ years of age before 10-valent pneumococcal conjugate vaccine introduction. BMC Public Health 16(1):1233. doi:10.1186/ s12889-016-3897-9.

Sato K, Okada S, Sugawara A, Tode N, Watanuki Z, Suzuki K, Ichinose M. 2016. Improving physical activity ensures the long-term survival of pneumonia patients in a superaged society: A retrospective study in an acute-care hospital in Japan. Tohoku J Exp Med 238(3):237-245. https://doi. org/10.1620/tjem.238.237.

Tomatala S, Kinasih A, Kurniasari MD, De Fretes F. 2019. Hubungan antara aktivitas fisik dengan kekambuhan ispa pada anak usia sekolah di kecamatan bringin kabupaten Semarang. Jurnal Keperawatan Respati Yogyakarta 6(1):537-541. https://doi. org/10.35842/jkry.v6i1.289.

Tongo MA, Sy RA. 2017. The relation of nutritional assessment and pneumonia severity index among elderly patients with community acquired pneumonia admitted at Cardinal Santos medical center. J Nutr Diet Suppl 1(1):102.

[UNICEF] United Nations Children's Fund. 2016. One Is Too Many: Ending Child Deaths From Pneumonia And Diarrhea. https://data.unicef.org/wpcontent/ uploads/2016/11/UNICEF-PneumoniaDiarrhoea-report2016-web\%20version. pdf. [Accessed 23rd August 2019].

[UNICEF] United Nations Children's Fund. 2018. One Is Too Many: Ending Child Deaths From Pneumonia And Diarrhea. https://data.unicef.org/wpcontent/ uploads/2018/11/UNICEF-PneumoniaDiarrhoea-report2018-web\%20version. pdf. [Accessed 23rd August 2019]

Widayat A. 2014. Faktor-faktoryang berhubungan dengan pneumonia pada balita di wilayah puskesmas mojogedang II Kabupaten Karanganyar [Undergraduate Thesis]. Jawa Tengah: Universitas Muhammadiyah Surakarta. 